\title{
Development of molecular tools to differentiate Indian wild pig (Sus scrofa cristatus) meat from exotic and local domestic pig meat
}

\author{
Kajal Kumar Jadav, Avadh Bihari Shrivastav and Nidhi Rajput \\ Centre for Wildlife Forensic and Health, \\ Nanaji Deshmukh Veterinary Science University, Jabalpur, Madhya Pradesh, India \\ Corresponding author: Kajal Kumar Jadav email: cwfh2010@gmail.com \\ Received: 25-07-2013, Revised: 03-09-2013, Accepted: 05-09-2013, Published online: 27-10-2013
}

doi: $10.14202 /$ vetworld.2013.919-922

How to cite this article: Jadav KK, Shrivastav AB and Rajput N (2013) Development of molecular tools to differentiate Indian wild pig (Sus scrofa cristatus) meat from exotic and local domestic pig meat, Veterinary World 6(11): 919-922.

\begin{abstract}
Aim: Identification of wild pig and domestic pig is essential to prevent illegal poaching of wild pig and to implement Wildlife (Protection) Act, 1972. PCR-RFLP was used to differentiate Wild pig (Sus scrofa cristatus) from Domestic pig (Sus scrofa domestica) meat.
\end{abstract}

Materials and Methods: DNA was isolated from meat samples of both the sub species and a fragment of Cytochrome $b$ gene was amplified using universal primers and the PCR products were subjected to restriction digestion.

Results: All the known samples of each of the sub-species amplified 474 bp fragment successfully using b1 and b2 primers. To differentiate between wild and domestic pig meat, restriction digestion of the PCR products was carried out to produce characteristic PCR-RFLP patterns for each species. StuI digestion yielded a RFLP pattern which distinguished the closely related sub species. The alignment of sequences of Wild pigs with sequences of local domestic pig, European wild pig and exotic breeds revealed 7 intra-species polymorphic sites within Cytochrome b gene fragment.

Conclusion: This study showed that The PCR-RFLP is a simple and very effective tool for differentiating the samples of both the sub species and could prove to be a useful tool in forensic identification of wild pig and domestic pig.

Keywords: cytochrome b gene, domestic pig, Indian wild pig, PCR-RFLP

\section{I ntroduction}

Indian wild pig (Sus scrofa cirstatus) is a protected species under Schedule III of the Indian Wildlife (Protection) Act, 1972 and a separate sub-species from the domestic pig (Sus scrofa domesticus), which is a source of meat and an important farm animal in many states of India [1]. Indian wild pig is extensively poached for meat and in the absence of simple differentiation protocol for meat identification of wild and domestic pigs, implementation of Wildlife (Protection) Act, 1972 remains a constraint.

Most of the methods used for identification of species of origin of meat have been reported to have limitations in use due to problems in specificity (i.e. sensory analysis, glycogen level, histological technique, tissue fat properties \& immunological methods), complexity (i.e. electrophoresis and DNA hybridization), high cost (i.e. DNA hybridization) and requirements of base line data (i.e. isoelectric focusing) [2]. DNA-based methods for meat identification include Polymerase Chain Reaction [3], Polymerase Chain Reaction-Restriction Fragment Length Polymorphism (PCR-RFLP) [4,5], Random Amplified Polymorphic DNA (RAPD) [6], Single Strand Conformational Polymorphism (SSCP) [7], nucleotide sequencing [8] and real time PCR [9]. Both nuclear and

Copyright: The authors. This article is an open access article licensed under the terms of the Creative Commons Attribution License (http://creativecommons.org/licenses/by/2.0) which permits unrestricted use, distribution and reproduction in any medium, provided the work is properly cited. mitochondrial DNA (mtDNA) has been used for these studies [3-9]. Due to maternal inheritance of mtDNA, no recombination mechanism exists as in the nuclear DNA to eliminate error once a mutation occurred [10]. Thus, accumulation of these point mutations allows discrimination of closely related species [11]. However, attempts on within species or closely related subspecies identification using simple PCR-RFLP method are scanty.

The cytochrome $b$ gene for species identifications have been used by many researchers as it is one of the bettered genes in the genbank and has superior ability for separating species when compared to other genes [12]. In the present study, the partial sequence of the Cytochrome b gene of Indian wild pig, domestic pig, European wild pig and exotic breeds were compared to develop a simple Polymerase Chain Reaction-Restriction Fragment Length Polymorphism (PCR-RFLP) assay.

\section{Materials and Methods}

Five known samples (meat) of each domestic and wild pig collected from fresh carcass were used for DNA isolation using DNeasy Blood \& Tissue Kit (QIAGEN, Germany) in a final elution volume of 300 $\mu 1$. The DNA was subjected to PCR amplification in a Gradient Thermal Cycler (Eppendrof, India) in a final volume of $50 \mu \mathrm{l}$ containing $200 \mathrm{ng}$ of extracted DNA, $10 \mathrm{mM}$ Tris- $\mathrm{HCl}(\mathrm{pH} 8.3), 50 \mathrm{mM} \mathrm{KCl}, 1.5 \mathrm{mM} \mathrm{MgCl}_{2}$, $200 \mu \mathrm{M}$ of each dNTPs (dATP, dCTP, dGTP and dTTP), 1.5 units of Taq DNA Polymerase, $0.5 \mu \mathrm{g} / \mu \mathrm{l}$ Bovine 
Table-1. Summary of polymorphic sites which can be used to differentiate Indian wild boar from local domestic pigs and exotic pigs (Duroc and Hampshire)

\begin{tabular}{|c|c|c|c|}
\hline $\begin{array}{l}\text { Polymorphic } \\
\text { site no. }\end{array}$ & Position ${ }^{a}$ & Wild pig & $\begin{array}{c}\text { European wild pig/Exotic } \\
\text { pig/local domestic pig }\end{array}$ \\
\hline 1 & 14310 & A & $\mathrm{G}$ \\
\hline 2 & 14388 & $\mathrm{~T}$ & C \\
\hline 3 & 14395 & $A$ & $\mathrm{G}$ \\
\hline 4 & 14448 & $\mathrm{~T}$ & C \\
\hline 5 & 14466 & C & $\mathrm{T}$ \\
\hline 6 & 14508 & $\mathrm{C}$ & $\mathrm{T}$ \\
\hline 7 & 14517 & $\mathrm{~T}$ & C \\
\hline
\end{tabular}

${ }^{a}$ Position of nucleotide in reference to FJ 237003

Serum Albumin (BSA) and 20pmol of each primer. The universal primers of Cytochrome $b$ gene fragment $(\mathrm{b} 1-$ 5 CCAATGATATGAAAAACCATCGTT 3 and b2- 5 GCCCCTCAGAATGATATTTGTCCTC 3 ) were used for PCR amplification [13]. The amplified product was subjected to electrophoresis on $1.2 \%$ agarose gel for 45 min at $70 \mathrm{~V}$ in Tris Acetate EDTA (TAE) buffer and gel was stained with ethidium bromide (Et br) $(0.5 \mu \mathrm{g} / \mathrm{ml})$. The amplification parameters were $95^{\circ} \mathrm{C}$ for 20 minutes followed by 35 cycles of $95^{\circ} \mathrm{c}$ for $1 \mathrm{~min}, 50^{\circ} \mathrm{c}$ for $1 \mathrm{~min}$ and $72^{\circ} \mathrm{c}$ for $1 \mathrm{~min}$ with final extension at $72^{\circ} \mathrm{C}$ for 10 minutes prior to a $4^{\circ} \mathrm{C}$ hold.

One PCR product of each subspecies were purified and sequenced in both directions using the BigDye ${ }^{\circledR}$ sequencing kit (Applied Biosystems, Foster City, California, USA). The obtained sequences have been submitted in Gene Bank under Accession No. KF185090 and KF185091. Three additional sequences of pig samples collected from forests of Western Ghats, one sequence each of European Wild pig, Hampshire and Duroc breed were retrieved from National Centre for Biotechnology Information (NCBI). The sequences were aligned using DNAstar program (DNAS Inc, Madison, WI, USA).

For differentiation, Cytochrome $b$ gene fragment sequences were analyzed by DNAStar software and StuI restriction enzyme ( $\mathrm{AGG}^{\downarrow} \mathrm{CCT}$ ) was used for RFLP analysis. The amplified PCR products were

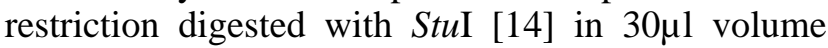
containing $3 \mu \mathrm{l} 10 \mathrm{X}$ buffer, $10 \mu \mathrm{l}$ of amplicon, $1 \mu \mathrm{l}$ engyme, $17 \mu 1$ nuclease free water and incubated at $37^{\circ} \mathrm{C}$ for overnight. The digested products were subjected to electrophoresis on $1.5 \%$ agarose gel at 1.5 $\mathrm{V} / \mathrm{cm}$ for 4 hours and stained with Et br. Band patterns were analyzed by Gel documentation System (AlphaDigi Doc RT, JH India Ltd).

\section{Results and Discussion}

Due to the relatively high copy number of mtDNA genomes per cell, mtDNA is more suitable than nuclear genome for studies on degraded or otherwise compromised materials [15]. Various genes

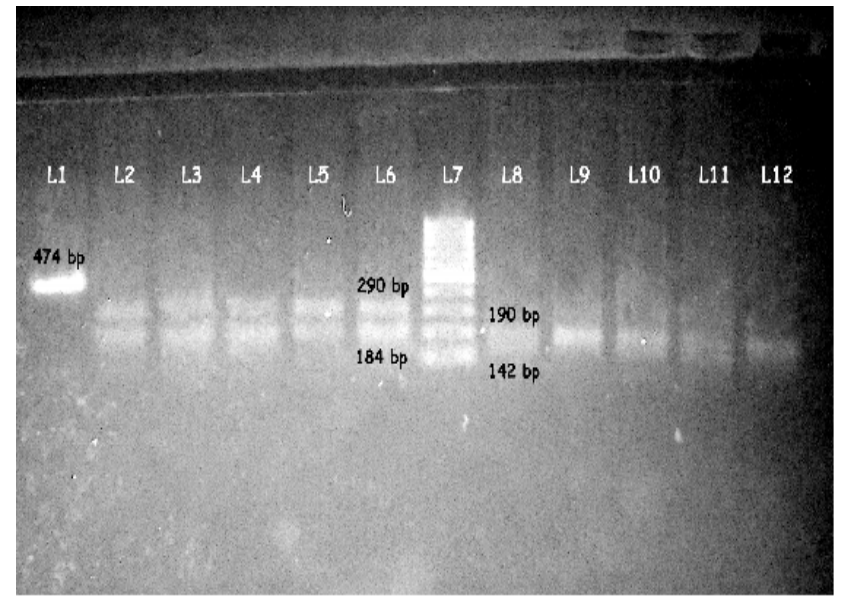

Figure-1. PCR-RFLP pattern produced by restriction digestion with Stul (L1: Undigested PCR product, L2-L6: Domestic pig, L7: 100bp Ladder, L8-L12: Wild pig)

of mtDNA i.e. cytochrome $b$ gene [16], 12S [17], 16S [18], 18S [19] ribosomal RNA (rRNA) subunit genes and displacement loop region (D-loop) [20] have been used for species identification.

All the known samples of each of the sub-species amplified $474 \mathrm{bp}$ fragment successfully using b1 and b2 primers. Jon et al. [21] have also used this primer in the ARMs PCR to determine the presence of tiger bone in Traditional Chinese Medicine (TCM). We validated the sequence authenticity by direct sequencing of one PCR product each of Indian Wild pig and domestic local pig. Together with these sequences, a total of 8 mitochondrial sequences of Cytochrome $b$ gene fragments were aligned to discern intra-species variations. Seven polymorphic sites were identified in the sequence of Indian wild pigs and sequences of samples collected from Western Ghats. Based on the intra-species variations, the Indian wild pig were discriminated by restriction digestion with StuI which generated bands of less than $200 \mathrm{bp}$ (two $142 \mathrm{bp}$ and one $190 \mathrm{bp}$ bands) while two bands of $290 \mathrm{bp}$ and 184 bp were observed for Indian wild pig and domestic pig, respectively, on $1.5 \%$ Agarose gel (Figure-1). Due to overlapping of bands of $142 \mathrm{bp}$ only two bands (142 bp and $190 \mathrm{bp}$ ) are visible on restriction digestion with $S t u I$ in wild pig. The RFLP patterns of StuI on amplified PCR product were highly specific. The sequence analysis of all the known samples of Indian wild pig revealed two StuI sites, while only one site of restriction was present in the amplified sequence of domestic pig, European wild pig and exotic breeds (Plate-1). The presence of $5^{\text {th }}$ polymorphic site ("C") at the position of 14466 (Table-1) created an additional restriction site for StuI.

Apart from these polymorphisms, at the position of 14370 and 14407, all the sequences of Indian origin had " $C$ " instead of " $T$ " in European wild pig, Duroc and Hampshire pig breeds.

Srilankan wild boar (Sus scrofa affinis) was differentiated from native village pig (Sus scrofa domestica) targeting two polymorphic sites of mitochondrial D loop and restriction digestion with 


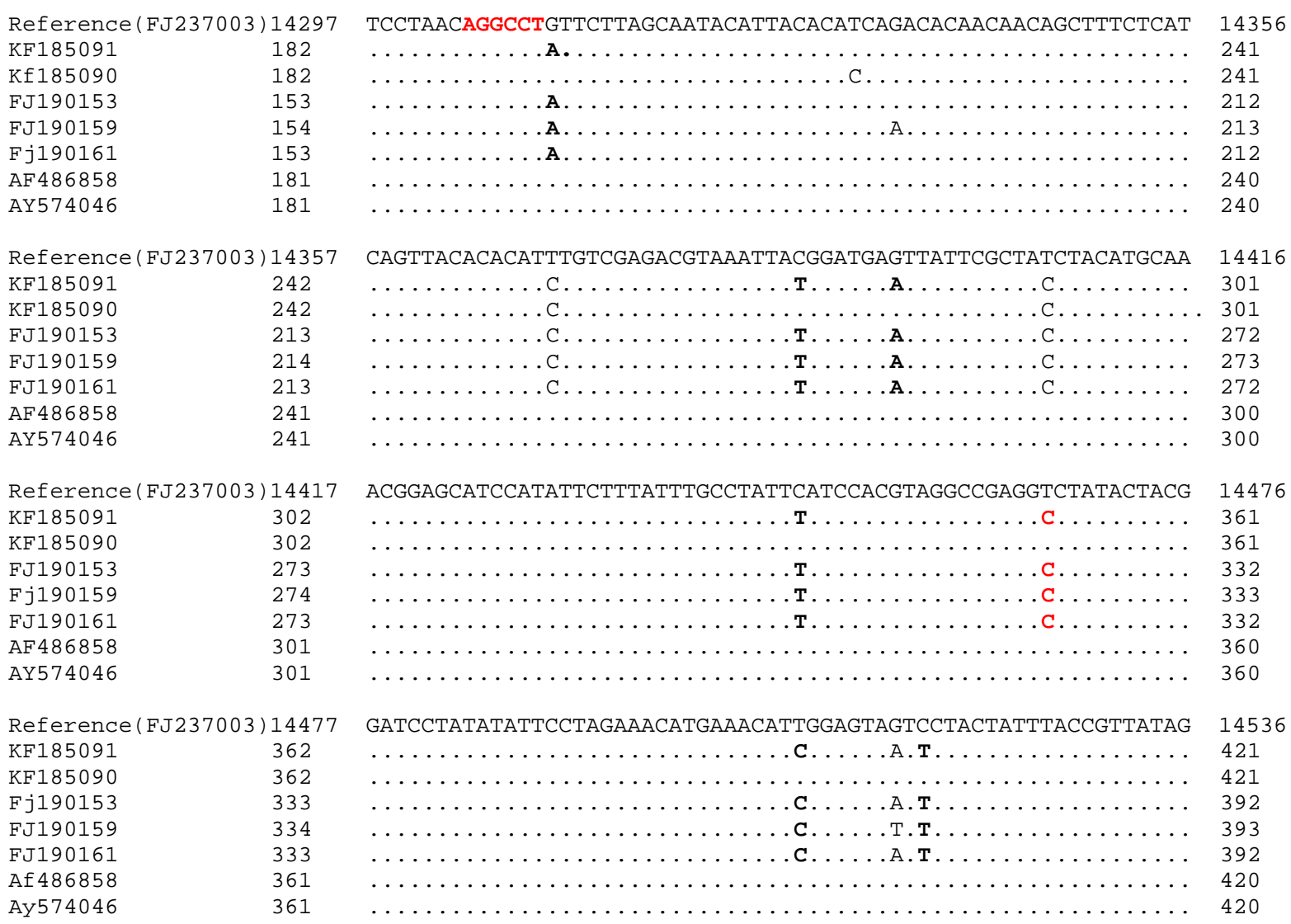

Plate-1. DNA sequence alignment of fragment of the Cytochrome b gene of selected wild boar, village pig and exotic pigs (Duroc, Land race \& Hampshire) from Table 1. Dot (.) indicates nucleotide identity according to the reference sequence (FJ 237003). Bold and highlighted nucleotide positions in the aligned sequence indicate the polymorphic sites of Indian wild boar from other pigs. The region used for restriction analysis (Stul - AGGCCT) is shown highlighted with red colour. Numbering is according to the gene bank sequence data. (FJ 237003-European wild bear; KF185091-Indian wild pig; KF185090-Domestic pig; FJ190153, FJ 190159, FJ 190161- Sequences from pigs of Western Ghat forests; AF486858-Duroc; AY574046-Hampshire breeds)

DraI enzyme and used European wild pig sequence as reference sequence to compare the sequences of village and exotic pigs [22]. Another Cytochrome b gene fragment (440 bp) of wild pig and domestic pig was sequenced previously to study the phylogenetics of the two sub species [1]. Though the DNA sequencing revealed unambiguous result, PCR-RFLP of $474 \mathrm{bp}$ Cytochrome $b$ gene fragment could prove a quick and cost effective tool in forensic analysis of seized samples. The recent introgression of exotic genome due to the state sponsored programs conducted to upgrade the local population with imported semen or live animals of exotic breeds has diluted the gene pool of local breeds and precise breed specification of the local domestic remains questionable. In most of these upgrading programs paternal and not maternal introgression is possible as it is the imported semen or boar that is used commonly in the breeding program. Owing to maternal inheritance, polymorphisms of mitochondrial genes provide means in species identification. The polymorphism observed in cytochrome $\mathrm{b}$ fragment sequence can be used to differentiate Indian wild boar from local domestic pigs, European wild pig and exotic pig breeds of Duroc and Hamshire.

Using the PCR-RFLP assay, we could resolve a forensic case registered under Damoh range, Madhya
Pradesh Forest Department, (Sample No. 25F/8.01. 2013) in which confiscated meat samples of heart and muscle tissue matched with RFLP pattern of wild pig while PCR-RFLP pattern of two other pieces of seized meats under the same case matched with the domestic pig profile (Figure- 2 ).

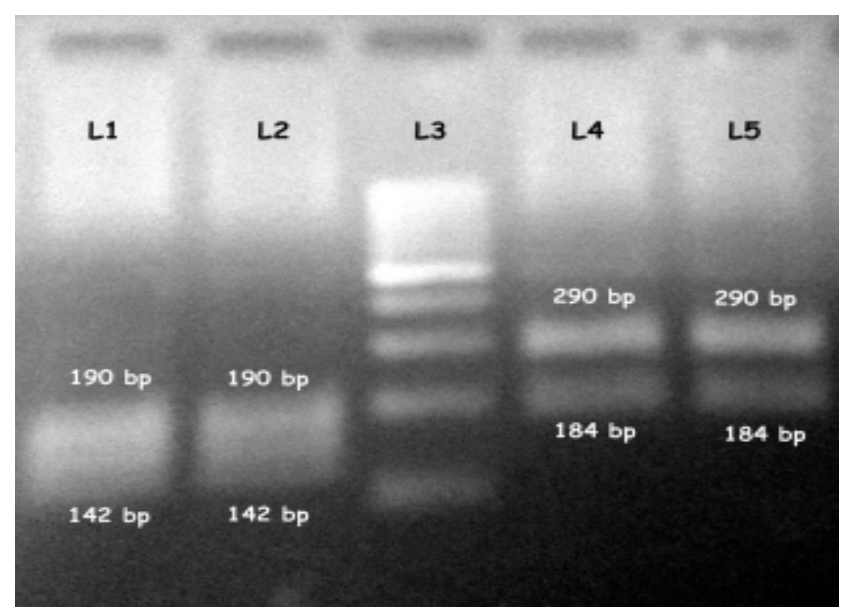

Figure-2. PCR-RFLP pattern produced by restriction digestion with Stul (L1, L2: Heart, Muscle sample, L3: 100bp Ladder, L4, L5: Meat sample)

\section{Conclusion}

In comparison to other phylogenetic marker, the cytochrome b gene demonstrates greater congruence 
with conventional mammalian phylogeny and shows greater level of nucleotide variation in shorter sequence [23]. The restriction pattern obtained by StuI enzyme on Cytochrome b gene fragment of $474 \mathrm{bp}$ was found to be efficient for differentiating the samples of wild and domestic pig. The PCR-RFLP is a simple and very effective tool for differentiating the samples of both the sub species of pigs, which can help law enforcing agencies like Forest department, Police authorities to identify the sub-species which in turn would help in prosecution of the poachers.

\section{Authors' contributions}

KKJ designed the study. NR and KKJ analyzed and interpreted the results. ABS drafted and revised the manuscript for critical scientific corrections. All authors read and approved the final manuscript.

\section{Acknowledgements}

Authors are thankful to Madhya Pradesh Forest Department and Vice-Chancellor, Nanaji Deshmukh Veterinary Science University, Jabalpur, for providing the necessary facilities. Necessary fund was provided by the Madhya Pradesh Forest department (India) through budget head number C-3 state 2(i) Establishment of Centre for Studies of Wildlife Health and Disease.

\section{Competing interests}

The authors declare that they have no competing interests.

\section{References}

1. Gupta, S.K., Kumar, A., Hussain, S.A., Vipin and Singh, L. (2013) Cytochrome $b$ basesd genetic differentiation of Indian wild pig (Sus scrofa cristatus) and domestic pig (Sus scrofa domestica) and its use in wildlife forensics, Sci. Justice, 53:220-222.

2. Ilhak, I.O. and Ali A. (2007) Identification of meat species by polymerase chain reaction (PCR) technique, Turk. J. Vet. Anim. Sci., 31: 159-163.

3. Guha, S. and Kashyap, V. K. (2005) Development of novel heminested PCR assays based on mitochondrial 16s rRNA gene for identification of seven pecora species, BMC Genet., 6:42.

4. Saini, M., Das, D.K., Dhara, A., Swarup, D., Sharma, A.K. and Gupta, P.K. (2008) A PCR-RFLP tool for differentiating cattle, buffalo and nilgai, Indian J. Anim. Sci., 78: 652-654.

5. Rajput, N., Shrivastav, A.B., Parmer, S.N.S., Ranjan, R., Singh, S. and Joseph, E. (2013) Characterization of $12 \mathrm{~S}$ rRNA gene for meat identification of common wild and domestic small herbivores as an aid to wildlife forensic, Vet. World, 6: 254-259.

6. Koh, M.C., Lim, C.H., Chua, S.B., Chew, S.T. and Phang, S.T.W. (1998) Random amplified polymorphic DNA (RAPD) finger printing for identification of red meat animal species, Meat Sci., 48:275-85.

7. Dooley, J. J., Paine, K.E. and Garrett, S.D. (2004) Detection of meat species using TaqMan real-time PCR assays, Meat
Sci., 68:431-438.

8. Colombo, F., Marchisio, E., Pizzini, A. and Cantoni, C. (2002) Identification of the goose species (Anser anser) in Italian "Mortara" salami by DNA sequencing and a polymerase chain reaction with an original primer pair, Meat Sci., 61: 291-94.

9. Sawyer, J., Wood, C., Shanahan, D., Gout, S. and McDowell, D. (2003) Real-time PCR for quantitative meat species testing, Food Control, 14:579-583.

10. Hwang, D.F., Jen, H.C. and Hsieh, Y.W. (2004) Applying DNA techniques to the identification of the species of dressed toasted eel products, J. Agr. Food Chem., 52: 59725977.

11. Wolf, C., Rentsch, J. and Hubner, P. (1999) PCR-FRLP analysis of mitochondrial DNA: A reliable method for species identification, J. Agr. Food Chem., 47: 1350-1355.

12. Sanches, A., Tokumoto, P.M., Peres, W.A.M., Nunes, F.L., Gotardi, M.S.T., Carvalho, C.S., Pelizzon, C., Godoi, T.G. and Galetti, M. (2012) Illegal hunting cases detected with molecular forensics in Brazil. Investig. Genet., 3(1):17.

13. Kocher, T.D., Thomas, W.K., Mayer, A., Edwards, S.V., Paabo, S.,Villablanca, F. X. and Wilson, A.C. (1989) Dynamics of mitochondrial DNA evolution in animals: amplification and sequencing of conserved primers. Proc. Natl. Acad. Sci. USA., 86: 6196-6200.

14. Sambrook, J. and Russell, D.W. (2001) Molecular cloning: a molecular approach laboratory manual. $3^{\text {rd }}$ edition. New York: Cold Spring Harbour Laboratory Press.

15. Alaeddini, R., Walsh, S.J. and Abbas, A. (2010) Forensic implications of genetic analyses from degraded DNA-a review, Forensic Sci. Int. Genet., 4:148-157.

16. Meganathan, P.R., Dubey, B. and Haque, I. (2009) Molecular identification of Indian crocodile species: PCRRFLP method for forensic authentification, J. Forensic Sci., 54:1042-1045.

17. Shi-Yi, C., Yong-Gang, Y. and Yi-Ping, L. (2012) Species identification of ten common farm animals based on mitochondrial 12S rRNA gene polymorphisms, Anim. Biotechnol., 23:213-220.

18. Borgo, R., Souty Grosset, C., Bouchon, D. and Gamot, L. (1996) PCR RFLP analysis of mitochondrial DNA for identification of snail, J. Food Sci., 61:1-4.

19. Matsunga, T., Shibata, K., Yamada, J., Shinmura, Y. and Chikuni, K. (1998) Identification of meat species based on different 18 S ribosomal genes, J. Jpn. Soc. Food Sci., 45: 719-723.

20. Rane, P.P and Barve, S.S. (2011) Standardization and Optimization of mtDNA isolation and molecular genetic analysis of D-loop region in animal natural fibres, Int. J. of Zool. Res., 7:190-200.

21. Jon, H.W., Carol, S., Tsang, F., Chris, A.R. and Adrian, C.S. (2004) An extremely sensitive species-specific ARMs PCR test for the presence of tiger bone DNA, Forensic Sci. Int., 140:139-145.

22. Samaraweera, M., Himali, S.M.C., Zeng, S.C., Jianlin, H. and Silva, P. (2011) Development of molecular tools to differentiate Sri Lankan wild Boar (Sus scrofa affinis) meat from exotic and village pig (Sus scrofa domestica) meat, Trop. Agr. Res., 23: $11-20$.

23. Tobe, S.S., Kitchener, A.C. and Linacre, A.M.T. (2010) Reconstructing mammalian phylogenetics: a detailed comparison of the cytochrome $\mathrm{b}$ and cytochrome oxidase subunit I mitochondrial gene, PloS One 11:e14156. 